\title{
Employee Branding Through Talent Management for Customer Satisfaction
}

\author{
Meera Singh ${ }^{1}$ \\ ${ }^{I}$ (Computer Department (H.S.S), G.H. Raisoni Institute of Engineering \& Technology/Pune University, India)
}

\begin{abstract}
The meaning of Employee branding to the company is actually the image of an organization for the people working in the organization. It is this reputation that the companies make of themselves inside their premises that are also carried outside to the customers, the clients and also the others who are affected by the proceedings of the company. Hence, one can say that within the company, employee branding is done to attract the employees, and also for their subsequent retention in times to come so as to improve the company's image as far as customer satisfaction is concerned. The management has to understand a very simple fact that it can't lay a narrow focus on the employee branding because it is very critical for overall business strategy of the company. One must keep another fact clear that if employee branding is only considered to be a part of the recruitment process and not emphasized as Talent management and then given the back seat, there will be too many cases of absenteeism resulting in subsequent resignations at frequent intervals along with the high employee turnover.
\end{abstract}

Keywords - Employee branding, Talent management, Customer satisfaction, Employee Turnover

\section{INTRODUCTION}

Employee branding is basically employee branding means what an employee projects about himself and the organization culture. A strong sense of affiliation is seen of the employee towards his/her organization. $\mathrm{He} / \mathrm{She}$ should be able to serve as a brand ambassador for his/her organization. In simple terms, employees' attitude and engagement towards the employer brand image promoted through the culture of the organization.

The Employee branding consists of the four important things i.e. by selective hiring /selective recruitment, providing targeted training /certifications for employees, effectively communicating the Organization goals \& what is expected, role clarity and the compensation system should incorporate messages that consistently and frequently reflect the brand and organizational image.

The employee branding is synonym phrase of Talent Management hence the Employee branding through Talent management for customer satisfaction can be easily attained by completely focusing on Talent Management. is basically constituent of five elements such as attracting, selecting, engaging, developing and retaining employees and it is generally concerned with identifying the talent gaps, succession planning, retaining talented employees by variety of initiatives as well as implementing different strategies. Employee and skill are very important weapons which gives competitive advantage to the company in cut throat competition.

There are few important things which should be implemented for Talent Management i.e. support of the CEO and top level management [2]. Motivation and Engagement is the key to Employee branding through Talent Management [3]. The engaged employees always indicate higher job satisfaction and have confidence in the future of the organization. To motivate talent is not really an easy task but if top management helps talent

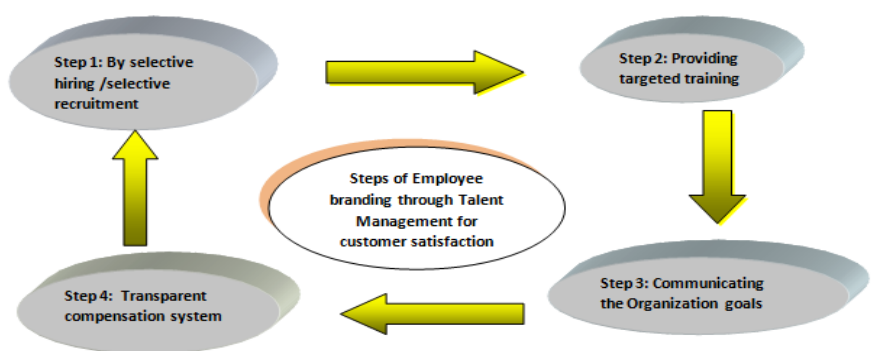

Fig. 1 Employee Branding Cycle

II.

\section{CURRENT Trend}

Organizations are concentrating on the strong exchange relationships; and an understanding of relationship value of a customer. There are a variety of factors that influence the development of strong customer relationships [1]. There is framework which suggests that relationship with customers occur at 
different levels and each successive level of strategies results in ties that bind the customer little closer to the firm.

\subsection{Level 1- Financial Bonds}

The customer is tied to the firm primarily through financial incentives i.e. lower prices for greater volume purchases or lower prices for customers who have been with the firm for a long time.

\subsection{Level 2- Social Bonds}

It binds customers to the firm through more than financial incentives. Firms build long-term relationships through social and interpersonal bonds. $\mathrm{Cu}$

whose needs and wants the firm seeks to understand.

\subsection{Level 3- Customization Bonds}

The two commonly used terms fit with the customization bond: mass customization and customer intimacy. These two strategies completely suggest that customer loyalty can be encouraged through intimate knowledge of individual customers and through development of individual solution that fit the individual

\subsection{Level 4-Structural Bonds}

Structural bonds are created by providing services to the client that are frequently designed right into the service delivery system for that client. It is generally created by providing customized services to the client that is technology based.

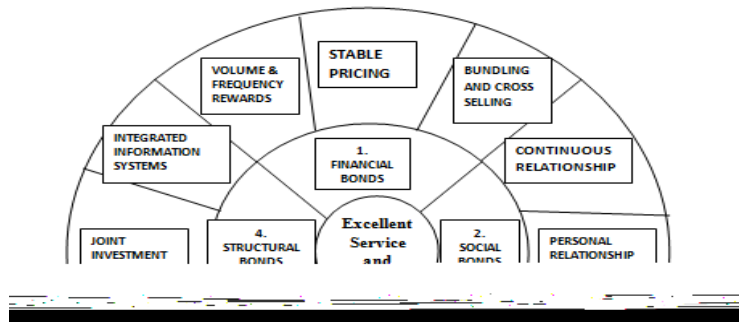

Fig. 2 Customer Relationship Management Cycle

But all these levels are monitored and implemented by the employees of a firm and hence a company really needs employee branding. At this point the company needs a pool of talented employees as far as production and services are concerned for satisfied customers.

The Employee branding is a conjuration and it can only be implemented by Talent management. Workforce is a greatest asset for any organisation [2]. It is the need of the hour to plan and implement Employee branding through Talent Management. The customer is king and hence to employ excellent work force is essential as these key players will satisfy the customer needs and demands hence organizations should attract, motivate, nurture and retain talent.

\section{EMPLOYEE BRANDING Through Talent Management: A Challenge}

The Employee branding through Talent Management means to have a strategic group of employees who can generate, design and develop the ideas, which can help the organization to sustain in the market. The top management has to empower the talents to change the organization [3]. The top management has to support their effort in pushing new ways of business through the organization.

\subsection{COST}

Due to cost cutting it is very difficult to recruit highly paid worker but, if we pay peanuts then only monkeys can be hired. This investment can be calculative decision only if they stay in an organisation for long and the company will be able to reap the benefits out of their calibre.

\subsection{GROWTH AND PROGRESS}

The role of the talented employee is remarkable in the organizational growth and this whole network tends to expand if these key players are retained in the organization.

\section{STRATEGIES FOR EMPLOYEE BRANDING THROUGH TALENT MANAGEMENT}

The various organizations have to Employee branding by bonding with the talented employees beyond the traditional relationship of an employer employee and work place relationship. Furthermore the available talent in the organisation should be the basis for corporate strategies related to Talent Management and retention of human resource. Following are the strategies of Employee branding through talent management: 


\subsection{Employee - Employer Relationship Management}

The relationship between the talented employees and the organisation should be amicable and friendly. The talented employees always have the vision beyond which pays in long term however for operational planning at times it sounds impossible but then with continuous monitoring and strategic planning it is always beneficial because they focus on the relationship bonds.

\subsection{Business Partner}

of belonging towards the organization. This acts as catalyst because they can easily realise that they are not servants but actually they are the decision makers and partners in sharing the profit.

\subsection{Power}

The talented workers should be allowed to be apart in the board meetings and also be allowed to express their opinion related to decisions on any kind of matter related to their area of expertise. The decisions taken by these talented employees should be considered as a firm opinion and the top level managers must implement it after a discussion.

\subsection{Company Representative}

The organization should encourage the talented employees to represent the company in various negotiations, committees, celebrations and argument.

\subsection{Succession Planning}

The companies should plan for career of talented employees as on fast track basis and their job should be challenging and competitive. The succession planning should focus on the following points:

4.5.1 Identifying the key players.

4.5.2 To give them responsibilities related to bigger roles related in near future so that they should be prepared for that responsibility.

4.5.3 The top level managers should focus in the overall development of these kinds of potential leaders.

4.5.4 Building a database that can keep a record of the key employees.

\subsection{Recognition}

The contributions of the employees should be recognized and they should be awarded in different functions [5]. Not only felicitation but they should be provided with the fast track promotions.

\subsection{Creative Environment at Work Place}

The organization should plan the job of the talented employees so that they should be given challenging, innovative and creative work in order to utilize their skills and potentialities to the fullest. This will not only enhance their performance but also enhance organisational efficiency and provide satisfied customers.

\subsection{Training and Development}

The key players should always be encouraged to learn new skills and techniques as well they should be guided and provided excellent training programmes to groom their technical and presentation skills.

\section{CONCLUSION}

This report is an overview of the past, present and future of the Employee branding through Talent management for customer satisfaction. This report takes a wide view of Talent management, as the biggest nd maintain a motivated and contended workforce for satisfied customers. Due to cut throat competition in the era of Globalization wherein there is emphasis on customer care and paradigm shifts in information technology as well as information technology enabled services necessitated the organizations to focus on management of skilled employees, talented workers and knowledge workers retention and motivation of the best talents through employee branding.

The top management has a very important role in the Employee branding for the organization. Their communication is essential and their trust to the talents is also very important. The organizations do not hire new employees, but the recognized talents are always welcome. The organizations, which empower their talents, have a better chance to have satisfied customers. The talents know about their qualities and when they feel a possibility to develop their skills and competencies, they will look for the opportunity to show their potential in other organization. This is a task for Human Resources to support the role of the Employee branding through Talent Management for satisfied customers.

\section{REFERENCES}

[1] Arthur Anderson, Best Practices: Building You Business with Customer-Focused Solutions (New York: Simon \& Schuster, 1998), $125-127$

[2] Gratton L., Living Strategy: Putting people at the heart of corporate purpose (Pearson Education, 2000).

[3] Warren, K. and Kourdi, J. People Power: Developing the talent to perform (Vola Press, 2003).

[4] Bradley T. Gale, Managing Customer Value (The Free Press, 1994)

[5] Lance A. Berger, Dorothy R. Berger, The Talent Management Handbook (McGraw-Hill books, 2004)

[6] Robert D. Buzzell \& Bradley T. Gale, The PIMS Principle: Linking Strategy to Performance (The Free Press, 1987) 